\title{
Fast decolorization of azo dyes in alkaline solutions by a thermostable metal-tolerant bacterial laccase and proposed degradation pathways
}

\author{
Laura E. Navas $^{1,4} \cdot$ Romina Carballo $^{2,4} \cdot$ Laura Levin $^{3,4} \cdot$ Marcelo F. Berretta $^{1,4}$ (D)
}

Received: 13 April 2020 / Accepted: 26 June 2020

(c) Springer Japan KK, part of Springer Nature 2020

\begin{abstract}
Biocatalytic decolorization of azo dyes is hampered by their recalcitrance and the characteristics of textile effluents. Alkaline $\mathrm{pH}$ and heavy metals present in colored wastewaters generally limit the activity of enzymes such as laccases of fungal origin; this has led to an increasing interest in bacterial laccases. In this work, the dye decolorization ability of LAC_2.9, a laccase from the thermophilic bacterial strain Thermus sp. 2.9, was investigated. Its resistance towards different $\mathrm{pHs}$ and toxic heavy metals frequently present in wastewaters was also characterized. LAC_ 2.9 was active and highly stable in the pH range of 5.0 to 9.0. Even at $100 \mathrm{mM} \mathrm{Cd}^{+2}, \mathrm{As}^{+5}$ and $\mathrm{Ni}^{+2} \mathrm{LAC} \_2.9$ retained $99 \%, 86 \%$ and $75 \%$ of its activity, respectively. LAC_2.9 was capable of decolorizing 98\% of Xylidine, 54\% of RBBR, 40\% of Gentian Violet, and 33\% of Methyl Orange after $24 \mathrm{~h}$ incubation at $\mathrm{pH} 9$, at $60^{\circ} \mathrm{C}$, without the addition of redox mediators. At acidic $\mathrm{pH}$, the presence of the mediator 1-hydroxybenzotriazole generally increased the catalytic effectiveness. We analyzed the degradation products of laccasetreated Xylidine and Methyl Orange by capillary electrophoresis and mass spectrometry, and propose a degradation pathway for these dyes. For its ability to decolorize recalcitrant dyes, at pH 9, and its stability under the tested conditions, LAC_2.9 could be effectively used to decolorize azo dyes in alkaline and heavy metal containing effluents.
\end{abstract}

Keywords Thermostable bacterial laccase $\cdot$ Thermus sp. 2.9 Azo dye $\cdot$ Decolorization

Communicated by I. Cann.

Electronic supplementary material The online version of this article (https://doi.org/10.1007/s00792-020-01186-w) contains supplementary material, which is available to authorized users.

Marcelo F. Berretta

berretta.marcelo@inta.gob.ar

1 Instituto de Microbiología y Zoología Agrícola (IABiMoINTA CONICET), Centro de Investigaciones en Ciencias Veterinarias y Agronómicas (CICVyA), Instituto Nacional de Tecnología Agropecuaria (INTA), Nicolás Repetto y De Los Reseros s/n. 1686 Hurlingham, Buenos Aires, Argentina

2 Instituto de Química y Fisicoquímica Biológicas (IQUIFIB-CONICET), Facultad de Farmacia y Bioquímica, Universidad de Buenos Aires, Junín 956, CP 1113 Buenos Aires, Argentina

3 Laboratorio de Micología Experimental, Facultad de Ciencias Exactas y Naturales, Departamento de Biodiversidad y Biología Experimental, Universidad de Buenos Aires, INMIBO-CONICET, Buenos Aires, Argentina

4 Consejo Nacional de Investigaciones Científicas y Técnicas (CONICET), Buenos Aires, Argentina

\author{
Abbreviations \\ RBBR Remazol Brilliant Blue R \\ HBT 1-Hydroxybenzotriazole \\ ABTS 2,2'-Azino-di-[3-ethylbenzthiazoline sulfonate] \\ pHBA Para-hydroxybenzoic acid \\ CE Capillary electrophoresis
}

\section{Introduction}

Laccases are multicopper oxidases (MCO) that couple the oxidation of a wide range of substrates with the reduction of molecular oxygen to water. Due to their ability to oxidize phenolic compounds, laccases can act on a variety of persistent environmental pollutants present in the waste of several industrial processes such as dyes from textile effluents (Singh et al. 2015; Unuofin et al. 2019). The colored effluents discharged into water bodies can cause an increase in biochemical oxygen demand (BOD) and chemical oxygen demand (COD) and decrease the transmittance of light, reducing the photosynthetic activity in these ecosystems. Additionally, the release of dyes into the environment is toxic to living organisms (Collivignarelli et al. 2019). The 
degradation processes in the treatment plants generally remove a low percentage of dye content and often result in by-products of greater toxicity, such as carcinogenic amines from azo dyes (Collivignarelli et al. 2019; Zaharia and Suteu 2012). Thus, the application of laccases for decolorization and detoxification of effluents from the textile industries is particularly attractive. The use of low-molecular weight compounds as redox mediators can broaden their oxidation range by forming stable radicals that may continue oxidizing large molecules and non-phenolic substrates (Blánquez et al. 2019).

There are many reports on fungal extracts and purified laccases combined with synthetic or natural mediators capable of decolorizing several groups of textile dyes (Unuofin et al. 2019). Fungal laccases are typically maximally active at acidic $\mathrm{pH}$, which limits their use in textile dyes-containing effluents that are generally alkaline due to the presence of auxiliary dyeing compounds (Kokol et al. 2007). In these conditions, bacterial laccases show more potential compared with fungal laccases, but still need further research (Blánquez et al. 2019; Guan et al. 2018; Ma et al. 2018). Decolorization of azo dyes by bacteria has been previously described (Blánquez et al. 2019; Garg and Tripathi 2016; Mandic et al. 2019) and potential degradation pathways have been identified (Thakur et al. 2014; Xia et al. 2019). Despite this, information on the mechanism of azo dyes degradation by purified bacterial laccases is limited. Pereira et al. (2009) proposed a mechanism for decolorization of the azo dye, Sudan Orange G, by CotA-laccase from Bacillus subtilis which uses radical coupling reactions that result in oligomers and potential polymers. Degradation of the azo dye Reactive blue 52 by laccase 12B from Bacillus amyloliquefaciens expressed in Escherichia coli was monitored by HPLC-DAD and the resulting precipitate was analyzed by FTIR spectroscopy. The solution contained a unique product peak without chromophore, while the aggregates (assigned to a polymeric form of the dye) retained the blue color (Loncar et al. 2013). Recently the mechanism for Evans blue decolorization by a mutant of CotA-laccase from Bacillus pumilus expressed in Pichia pastoris was analyzed through liquid chromatography-mass spectrometry; the azo bond $(-\mathrm{N}=\mathrm{N}-)$ was transformed into $\mathrm{N}_{2}$ instead of toxic aniline compounds, in which water was the only by-product in the degradation process. Moreover, biological toxicity test showed that this laccase could efficiently detoxify Evans blue (Xia et al. 2019).

We have previously reported the expression and biochemical characterization of a bacterial laccase (LAC_2.9) from the thermophilic strain Thermus sp. 2.9 and evaluated its ability to modify lignocellulosic biomass (Navas et al. 2019). In this work, we investigated the decolorization ability of LAC_2.9 on different types of dyes, and the effect of two redox mediators in the process. We also characterized the resistance of the enzyme towards different $\mathrm{pHs}$, and toxic heavy metals frequently present in wastewaters. Additionally, insights into the mechanism of LAC_2.9 action on the azo dyes Xylidine and Methyl Orange are presented.

\section{Materials and methods}

\section{Enzyme preparation}

Recombinant LAC_2.9 was expressed in E. coli and purified as described previously (Navas et al. 2019). Briefly, genomic DNA from Thermus sp. 2.9 was used to amplify the gene coding for LAC_2.9 fused to an N-terminal 6xHis tag by PCR. The product was cloned into vector pJexpress 404 (DNA2.0) and the recombinant plasmid was transformed into E. coli. Expression of LAC_2.9 was induced by adding IPTG ( $1 \mathrm{mM}$ final) to the LB medium when the culture reached an $\mathrm{OD}_{600}$ of 0.8 together with $\mathrm{CuSO}_{4}(0.5 \mathrm{mM}$ final). The soluble LAC_2.9 was purified using a Ni-NTA affinity column. Purified LAC_2.9 activity was detected colorimetrically measuring the absorbance at $436 \mathrm{~nm}$ ( $\left.\varepsilon=36,000 \mathrm{M}^{-1} \mathrm{~cm}^{-1}\right)$ of oxidized ABTS (2,2'-azino-di[3-ethylbenzthiazoline sulfonate]). Assays were performed at $60{ }^{\circ} \mathrm{C}$ and contained $1 \mathrm{mM} \mathrm{CuSO}_{4}$ and $3 \mathrm{mM}$ ABTS in Britton-Robinson buffer pH 5.0 (Mongay and Cerdà 1974). One unit (U) of laccase activity was defined as the amount of enzyme needed to oxidize $1 \mu \mathrm{mol}$ of ABTS in $1 \mathrm{~min}$.

\section{pH stability and effect of metal ions on activity of LAC_2.9}

To evaluate the effect of cations on LAC_2.9, each one of $\mathrm{Cd}\left(\mathrm{NO}_{3}\right)_{2}, \mathrm{Cr}\left(\mathrm{NO}_{3}\right)_{3}, \mathrm{~Pb}\left(\mathrm{NO}_{3}\right)_{2}, \mathrm{NiSO}_{4}$ and $\mathrm{Na}_{2} \mathrm{HAsO}_{4}$ was added at final concentrations of 1,10 and $100 \mathrm{mM}$, to the reaction conducted at $\mathrm{pH} 5.0$ and containing $1 \mathrm{mM} \mathrm{Cu} \mathrm{SO}_{4}$, which was taken as control for $100 \%$ activity. The effect of $\mathrm{CuSO}_{4}$ at 10 and $100 \mathrm{mM}$ was also examined. The $\mathrm{pH}$ stability of LAC_ 2.9 was evaluated by determining the residual activity of the enzyme after $24 \mathrm{~h}$ incubation at $25^{\circ} \mathrm{C}$ in Britton-Robinson buffer at pHs 5.0, 7.0 and 9.0, using ABTS as substrate.

\section{In vitro decolorization of dyes by LAC_2.9}

The decolorization assays were performed in Britton-Robinson buffer at three $\mathrm{pH}$ values $(5.0,7.0$ and 9.0$)$ in $0.5 \mathrm{ml}$ volume containing the dye (at the concentration required for each dye to obtain 1.0 absorbance units at its maximum wavelength), $1 \mathrm{mM} \mathrm{CuSO} 4$, and $0.075 \mathrm{U}$ of purified LAC_2.9. When added to the reaction, the redox mediator [1-hydroxybenzotriazole (HBT) or para-hydroxybenzoic acid (pHBA), Sigma] was set to $0.5 \mathrm{mM}$. Reactions were incubated at $60{ }^{\circ} \mathrm{C}$. Absorbance was measured after 
6 and $24 \mathrm{~h}$ for reactions containing the following dyes, at the indicated wavelengths: azo dyes, Xylidine (Ponceau $\left.2 \mathrm{R}, \lambda_{\max }=505 \mathrm{~nm}\right)$ and Methyl Orange $\left(\lambda_{\max }=460 \mathrm{~nm}\right)$; triphenylmethane dyes, Malachite Green $\left(\lambda_{\max }=618 \mathrm{~nm}\right)$ and Gentian Violet $\left(\lambda_{\max }=590 \mathrm{~nm}\right)$, the antraquinone dye, Remazol Brilliant Blue R (RBBR) $\left(\lambda_{\max }=590 \mathrm{~nm}\right)$; and the indigoid dye Indigo Carmine $\left(\lambda_{\max }=608 \mathrm{~nm}\right)$. Controls without laccase were conducted in parallel. All the reactions were performed in triplicate. Decolorization activity was calculated: \% Decolorization $=[(I-F) / I] \times 100$, where $I=$ initial absorbance and $F=$ absorbance of decolorized reaction (Parshetti et al. 2006).

\section{Electrochemical measurements}

Electrochemical experiments were carried out with a potentiostat (TEQ, Argentina), provided with a digital signal generator for implementation of different electrochemical techniques. A glassy carbon working electrode $\left(0.25 \mathrm{~cm}^{2}\right.$ area), an $\mathrm{Ag} / \mathrm{AgClKCl} 3 \mathrm{M}$ reference electrode (BAS) and a platinum wire auxiliary electrode were used for differential pulse polarography (DPP). DPP experiments were carried out using a potential ramp starting at $0.0 \mathrm{~V}$ and going up to $+0.800 \mathrm{~V}$ or $+0.900 \mathrm{~V}$ ( $\mathrm{vs} \mathrm{Ag} / \mathrm{AgCl}$ ) in a pulsed manner. The following experimental parameters were employed: potential step $=0.5 \mathrm{mV}$, pulse width $=0.06 \mathrm{~s}$, pulse amplitude $=50 \mathrm{mV}$, and pulse period $=0.2 \mathrm{~s}$.

\section{Capillary electrophoresis-mass spectra analysis}

Laccase or laccase/HBT decolorized azo dyes (after $24 \mathrm{~h}$ incubation at $\mathrm{pH} 7$ ) were analyzed by capillary electrophoresis (CE) and mass spectra (MS) and compared with the control without the enzyme. Initial dye concentration was respectively $33.6 \mathrm{mg} \mathrm{l}^{-1}$ and $18.3 \mathrm{mg} \mathrm{l}^{-1}$ for Xylidine and Methyl Orange. About the electrophoresis, separations were performed in a P/ACE MDQ (Beckman Coulter, Brea, CA, USA), equipped with a UV-Vis photodiode array detector. The software 32 KaratTM (Beckman Coulter) was used for data processing. All capillary electrophoresis experiments were performed at $25{ }^{\circ} \mathrm{C}$. UV detection was carried out at 254, 460 and $505 \mathrm{~nm}$. An untreated fused-silica capillary (Polymicro Technologies, Phoenix, AZ, USA) of $75 \mu \mathrm{m}$ I.D. $\times 375 \mathrm{~mm}$ O.D. was used. Its total length was $62 \mathrm{~cm}$ and the effective length was $50 \mathrm{~cm}$ to the detector. The background electrolyte solution (BGE) consisted of $50 \mathrm{mM}$ ammonium carbonate buffer ( $\mathrm{pH}$ 9.5). After each run, the capillary was washed with $0.1 \mathrm{M} \mathrm{NaOH}$ for $5 \mathrm{~min}$, then rinsed with distilled water for $3 \mathrm{~min}$ and BGE for $4 \mathrm{~min}$. Aliquots of the sample solutions were introduced by $5 \mathrm{~s}$ at $3.5 \mathrm{kPa}$ and the separation voltage was $20 \mathrm{kV}$. Finally, the capillary was flushed with water for $10 \mathrm{~min}$ at end of the day (Takeda et al. 1999). Mass spectrometric detection was performed using a
Thermo Scientific TSQ Quantum Access MAX triple quadrupole system Mass Spectrometer (Thermo Scientific, CA, USA) with electrospray ionization. Ionization in negative ion mode was registered. The spray voltage was set at $3500 \mathrm{~V}$. Nitrogen was employed as the nebulizer and auxiliary gas, set at 60 and 20 arbitrary units, respectively. The capillary temperature and vaporizer were set at $275^{\circ} \mathrm{C}$ and $350{ }^{\circ} \mathrm{C}$, respectively. For collision-induced dissociation, $99.997 \%$ argon (Grade 4.7) was used at 1.5 mTorr.

\section{Chemicals}

Indigo Carmine was from ICN (Costa Mesa, CA, USA), Malachite Green from Mallinckrodt (Phillipsburg, NJ, USA). All other chemicals were from Sigma (St. Louis, MO, USA).

\section{Statistical analysis}

The data presented are mean values of triplicate assays with a standard error of less than 5\%. Infostat software (Di Rienzo et al. 2017) was used to analyze the variance. The significant differences among treatments were compared by Tukey's multiple range test at $5 \%$ level of probability.

\section{Results and discussion}

\section{In vitro decolorization of dyes by LAC_2.9}

In this paper, the decolorization of two azo dyes with diverse structural configurations, two triphenylmethane dyes, an anthraquinonic dye and an indigoid dye was investigated at three different pHs using purified LAC_2.9. The dyes were decolorized with variable efficiency depending on their structural class and the $\mathrm{pH}$ of the reaction (Table 1). Results at pHs 7 and 9 are not shown for Indigo Carmine and Malachite Green as both dyes were decolorized at these $\mathrm{pHs}$ in the control reactions without enzyme. LAC_2.9 fully decolorized the dye Indigo Carmine without the addition of redox mediators after $6 \mathrm{~h}$ at $\mathrm{pH}$. The optimal $\mathrm{pH}$ for the decolorization activity of LAC_2.9 depended on the dye assayed. For example, LAC_2.9 displayed higher activity at acidic $\mathrm{pH}$ with Methyl Orange, and at alkaline $\mathrm{pH}$ with Xylidine. The results showed that at acidic $\mathrm{pH}$, the presence of HBT increased the catalytic effectiveness better than pHBA, which only improved LAC_2.9 Gentian Violet decolorization efficiency at pHs 7 and 9 (Table 1). Nevertheless, LAC_2.9 was capable of decolorizing 98\% of Xylidine, $54 \%$ of RBBR, $40 \%$ of Gentian Violet, and 33\% of Methyl Orange after $24 \mathrm{~h}$ incubation without the addition of redox mediators at $\mathrm{pH} 9$. Activity at this $\mathrm{pH}$ demonstrates the potential for treatment of wastewater effluents. 
Table 1 Percentage of dye decolorization after 6 and $24 \mathrm{~h}$ incubation with $0.15 \mathrm{U} / \mathrm{ml} \mathrm{LAC} \_2.9$ at $60{ }^{\circ} \mathrm{C}$ with or without the addition of HBT or pHBA redox mediators. Values represent the mean of three

\begin{tabular}{|c|c|c|c|c|c|c|c|}
\hline \multirow[t]{2}{*}{ Dye } & \multirow[t]{2}{*}{ Treatment } & \multicolumn{2}{|l|}{ pH 5} & \multicolumn{2}{|l|}{ pH 7} & \multicolumn{2}{|l|}{ pH 9} \\
\hline & & $6 \mathrm{~h}$ & $24 \mathrm{~h}$ & $6 \mathrm{~h}$ & $24 \mathrm{~h}$ & $6 \mathrm{~h}$ & $24 \mathrm{~h}$ \\
\hline \multirow[t]{3}{*}{ Methyl Orange } & LAC_2.9 & $23.50 \pm 1.82^{\mathrm{a} \#}$ & $50.95 \pm 1.35^{*}$ & $20.64 \pm 1.73^{\& a}$ & $24.36 \pm 1.00^{\mathrm{d}}$ & $19.58 \pm 1.74^{\$ a}$ & $33.45 \pm 2.14^{\Delta \mathrm{d}}$ \\
\hline & LAC_2.9+HBT & $61.55 \pm 2.24$ & $68.03 \pm 2.37$ & $24.10 \pm 2.04^{\& b}$ & $36.06 \pm 1.05^{\bullet e}$ & $28.67 \pm 2.01^{\$ b}$ & $39.19 \pm 1.44^{\Delta \mathrm{e}}$ \\
\hline & LAC_2.9+pHBA & $31.67 \pm 1.61^{\#}$ & $52.92 \pm 2.59 *$ & $26.76 \pm 3.79^{\& c}$ & $37.22 \pm 3.00^{\bullet f}$ & $27.60 \pm 3.44^{\$ c}$ & $37.32 \pm 2.42^{\Delta \mathrm{f}}$ \\
\hline \multirow[t]{3}{*}{ Xylidine } & LAC_2.9 & $34.31 \pm 2.34^{\mathfrak{f}}$ & $59.96 \pm 1.15^{\pi}$ & $52.72 \pm 5.10^{\Phi}$ & $81.23 \pm 2.53^{\lambda}$ & $72.06 \pm 1.93^{x}$ & $97.93 \pm 2.69^{6}$ \\
\hline & LAC_2.9+HBT & $47.19 \pm 2.13^{\mathrm{g}}$ & $86.04 \pm 3.94^{\mathrm{h}}$ & $51.75 \pm 2.04^{\Phi \mathrm{g}}$ & $80.97 \pm 0.95^{\lambda \mathrm{h}}$ & $75.50 \pm 1.03^{x}$ & $99.36 \pm 0.76^{6}$ \\
\hline & LAC_2.9+pHBA & $36.72 \pm 1.74^{£}$ & $63.33 \pm 1.46^{\pi \mathrm{i}}$ & $44.56 \pm 2.23$ & $68.28 \pm 1.51^{\mathrm{i}}$ & $69.04 \pm 0.69^{x}$ & $91.10 \pm 0.71^{\sigma}$ \\
\hline \multirow[t]{3}{*}{ Gentian Violet } & LAC_2.9 & $12.46 \pm 1.71^{\mathrm{j}}$ & $30.96 \pm 1.50^{\mathrm{m}}$ & $22.97 \pm 1.69^{\ddagger j}$ & $36.57 \pm 1.12^{\mathrm{m}}$ & $30.40 \pm 1.39^{\mp}$ & $40.07 \pm 2.02^{€ \mathrm{~m}}$ \\
\hline & LAC_2.9+HBT & $55.35 \pm 1.37$ & $73.86 \pm 2.05$ & $24.71 \pm 1.27^{\mathrm{k}}$ & $50.70 \pm 2.10^{\dagger \mathrm{n}}$ & $28.92 \pm 0.98^{\mp \mathrm{k}}$ & $44.26 \pm 0.59^{€ n}$ \\
\hline & LAC_2.9+pHBA & $21.82 \pm 1.16$ & $54.14 \pm 2.04$ & $40.07 \pm 1.70^{1}$ & $59.16 \pm 1.65^{\dagger}$ & $52.73 \pm 0.75^{1}$ & $53.49 \pm 2.68^{€}$ \\
\hline \multirow[t]{3}{*}{ Malachite Green } & LAC_2.9 & $52.31 \pm 2.68^{\infty}$ & $71.59 \pm 2.40^{f}$ & & & & \\
\hline & LAC_2.9+HBT & $82.35 \pm 0.72$ & $82.35 \pm 0.29$ f & & & & \\
\hline & LAC_2.9+pHBA & $52.47 \pm 2.27^{\infty}$ & $73.21 \pm 1.82^{f}$ & & & & \\
\hline \multirow[t]{3}{*}{$\operatorname{RBBR}^{\mathrm{X}}$} & LAC_2.9 & $34.61 \pm 1.82$ & $51.28 \pm 1.35^{\mathrm{t}}$ & $55.99 \pm 1.84^{\mathrm{q}}$ & $66.48 \pm 1.03$ & $53.61 \pm 1.93^{\mathrm{q}}$ & $54.04 \pm 2.69^{t}$ \\
\hline & LAC_2.9+HBT & $36.72 \pm 1.24$ & $56.10 \pm 2.37^{u}$ & $55.40 \pm 2.78^{r}$ & $64.22 \pm 3.14^{\mathrm{u}}$ & $54.72 \pm 1.03^{r}$ & $58.44 \pm 0.76^{\mathrm{u}}$ \\
\hline & LAC_2.9+pHBA & $34.36 \pm 1.61$ & $51.91 \pm 2.59^{w}$ & $41.56 \pm 2.48^{\mathrm{s}}$ & $58.26 \pm 2.99$ & $48.05 \pm 0.69^{\mathrm{s}}$ & $57.44 \pm 0.71^{\mathrm{w}}$ \\
\hline \multirow[t]{3}{*}{ Indigo Carmine ${ }^{\mathrm{X}}$} & LAC_2.9 & $97.90 \pm 2.16$ & & & & & \\
\hline & LAC_2.9+HBT & $99.10 \pm 1.06$ & & & & & \\
\hline & LAC_2.9+pHBA & $99.60 \pm 0.98$ & & & & & \\
\hline
\end{tabular}

The significant differences among treatments with laccase or laccase-mediator systems (1); and among pHs assayed (2) were compared by Tukey's multiple range test at $5 \%$ level of probability

(1) Means superscripted with the same symbol are not significantly different $(p<0.05)$

(2) Means superscripted with the same letter are not significantly different $(p<0.05)$

$\mathrm{x}_{\text {Means not significantly different among treatments }(p<0.05)}$

The purified recombinant bacterial laccase SilA from Streptomyces ipomoeae CECT 3341 was also active over wide temperature and $\mathrm{pH}$ ranges and it decolorized dyes of diverse chemical structures: 30,14 and $10 \%$ of the azoic dyes Reactive Black 5, Orange II and Tartrazine, and $12 \%$ of the triphenylmethane dye Cresol Red after $24 \mathrm{~h}$ incubation at $35^{\circ} \mathrm{C}$ and $\mathrm{pH} 8$ (Blánquez et al. 2019), but this enzyme could not decolorized the azoic dye Acid Orange 63 and the anthraquinonic Acid Black 48 without the addition of redox mediators. The recombinant laccase from Streptomyces cyaneus was also incapable of decolorizing the azo dye Orange II (Moya et al. 2010). However, a thermostable laccase from Thermus thermophilus SG0.5JP17-16 expressed in P. pastoris decolorized 100\%, 94\%, 94\% of the azoic dyes Congo Red, Reactive Black B and Reactive Black WNN, respectively, and $73 \%$ of the anthraquinonic RBBR, after $24 \mathrm{~h}$ incubation at $70{ }^{\circ} \mathrm{C}$ and $\mathrm{pH} 7.5$ (Liu et al. 2015). The purified laccase from Geobacillus thermocatenulatus decolorized $60 \%$ of Congo Red after $6 \mathrm{~h}$ of incubation and up to 99\% after $32 \mathrm{~h}$ of incubation (Verma and Shirkot 2014).

Regarding the mono-azo dyes with different molecular configuration that were assayed, Xylidine was decolorized more efficiently than Methyl Orange by purified LAC_2.9, with $98 \%$ decolorization attained at $\mathrm{pH} 9$ after $24 \mathrm{~h}$ of incubation (Table 1). Decolorization of Methyl Orange was most efficient at $\mathrm{pH} 5$, in presence of HBT (68\% after $24 \mathrm{~h}$ ). The structural heterogeneity influences the charge density distribution of the dye's molecules and hence their redox potentials (Ciullini et al. 2008). In turn, the relationship between the redox potential of the laccase and the dye substrate is a critical factor in the decolorization process of these compounds. Fungal laccases with high redox potential can oxidize a wide range of substrates; but bacterial laccases usually possess low and medium redox potentials [i.e. SilA of S. ipomoeae, $337 \mathrm{mV}$ (Blánquez et al. 2019); B. subtilis CotA, $455 \mathrm{mV}$ (Pereira et al., 2009)] limiting their oxidative ability. Nevertheless, the redox potential of the Stenotrophomonas maltophilia AAP56 laccase was determined at $638 \mathrm{mV}$ (Galai et al. 2014). The best efficiency in Xylidine decolorization at alkaline pHs can be explained by the shift of dye redox potential from $750 \mathrm{mV}$ (at pH 5) to $530 \mathrm{mV}$ (at pHs 7 or 9), thus decreasing the need of HBT addition (HBT redox potential $710 \mathrm{mV}$ ) (Supplementary Material, Fig. 1a-f). Therefore, the enzymatic oxidation of Xylidine 
is favored when Xylidine ortho hydroxyl group is deprotonated. Conversely, when Methyl Orange is oxidized by LAC_2.9, the redox mediator contributes by reducing the redox potential of the substrate (from 580 to $530 \mathrm{mV}$ ) (Supplementary Material, Figure 1g, h).

\section{pH-stability of LAC_2.9 and effect of metal ions on activity}

The $\mathrm{pH}$ optimum of activity of LAC_2.9 varies depending on the substrate, e.g. 5.0 for ABTS, and 6.0 for 2,6-dimethoxyphenol (DMP) (Navas et al. 2019). To evaluate the $\mathrm{pH}$ stability of LAC 2.9 the activity of the enzyme was determined after $24 \mathrm{~h}$ incubation at room temperature at three different $\mathrm{pHs}(5.0,7.0,9.0)$. Percentages of relative activity were respectively $90.3 \pm 8.3,101.8 \pm 2.1$ and $94.4 \pm 17.0$. The high residual activity of the enzyme at the three $\mathrm{pHs}$ assayed indicates that the decolorization of dyes at these $\mathrm{pH}$ values was not affected by enzyme instability in the reaction through incubation time.

The effect on the activity of LAC_2.9 of several metal ions frequently present in textile effluents was also evaluated. Each of these was assessed at concentrations 1, 10 and $100 \mathrm{mM}$ (Table 2). When assaying acidic cations such as $\mathrm{Cr}^{+3}$ and $\mathrm{Pb}^{+2}$ at high concentrations a precipitate was formed (Burriel Marti et al. 2002), which prevented spectrophotometric determination. Neither of the other metal ions tested showed a remarkable inhibitory effect on laccase activity up to a concentration of $10 \mathrm{mM}$. Even at $100 \mathrm{mM}$ LAC_2.9 retained $99 \%, 86 \%$ and $75 \%$ of its activity with $\mathrm{Cd}^{2+}, \mathrm{As}^{5+}$ and $\mathrm{Ni}^{2+}$ respectively, but only $31 \%$ with $\mathrm{Cu}^{2+}$. Earlier reports also showed that $\mathrm{Cu}^{2+}$ can inhibit substrate conversion by laccase (Kim and Nicell 2006) possibly through interruption of the enzyme electron transport system (Torres et al. 2003).

These results supply more evidence of LAC_2.9 robustness for industrial applications. The thermal stability of LAC_2.9 was assessed previously (Navas et al. 2019).

Table 2 Effect of metal ions on the activity of LAC_2.9 laccase

\begin{tabular}{llll}
\hline Metal ion & \multicolumn{2}{l}{$\%$ Relative activity } \\
\cline { 2 - 4 } & $1 \mathrm{mM}$ & $10 \mathrm{mM}$ & $100 \mathrm{mM}$ \\
\hline $\mathrm{Cu}^{2+}$ & 100.0 & $90.9 \pm 9.2$ & $31.2 \pm 4.8$ \\
$\mathrm{Cd}^{2+}$ & $100.7 \pm 6.4$ & $102.9 \pm 6.0$ & $98.9 \pm 4.6$ \\
$\mathrm{Cr}^{3+}$ & $100.1 \pm 18.2$ & $\mathrm{ND}$ & $\mathrm{ND}$ \\
$\mathrm{Pb}^{2+}$ & $105.6 \pm 4.0$ & $96.0 \pm 5.4$ & $\mathrm{ND}$ \\
$\mathrm{Ni}^{2+}$ & $97.3 \pm 9.8$ & $97.1 \pm 6.7$ & $74.7 \pm 7.3$ \\
$\mathrm{As}^{5+}$ & $107.0 \pm 5.9$ & $101.2 \pm 5.6$ & $85.8 \pm 6.3$ \\
\hline
\end{tabular}

$N D$ a precipitate was formed, which prevented spectrophotometric determination

${ }^{\text {a }}$ Laccase activity in the presence of $1 \mathrm{mM} \mathrm{Cu}^{2+}$ was set to $100 \%$
After $16 \mathrm{~h}$ at $60{ }^{\circ} \mathrm{C}$ LAC_2.9 showed no decrease of activity, and retained $80 \%$ activity after $16 \mathrm{~h}$ at $70{ }^{\circ} \mathrm{C}$ and after $6 \mathrm{~h}$ at $80{ }^{\circ} \mathrm{C}$. The effect of $\mathrm{Mg}^{2+}, \mathrm{Mn}^{2+}, \mathrm{Zn}^{2+}, \mathrm{Ca}^{2+}$, sodium dodecyl sulfate (SDS), ethylenediaminetetraacetic acid (EDTA), dithiothreitol (DTT) and $\mathrm{NaCl}$ on the activity of LAC_2.9 was also evaluated by Navas et al. (2019). Each of these reagents was tested at a concentration of $1 \mathrm{mM}$ and $\mathrm{NaCl}$ also at 10 and $100 \mathrm{mM}$. With respect to metal ions, LAC_2.9 was more resistant than LacTT from T. thermophilus SG0.5JP17-16 (Liu et al. 2015).

\section{Proposed mechanism for Xylidine and Methyl Orange decolorization by LAC_2.9}

We performed two analytical methodologies to evaluate the mechanism involved in the decolorization of the azo dyes at pH 7: capillary electrophoresis (CE) and mass spectrometry (MS). The results of CE are shown in Fig. 1 (absorbance detected at $254 \mathrm{~nm}$ ) and Supplementary Material, Fig. 2 (wavelengths in the visible spectrum). The electrophoretic profile of Xylidine appeared between 8 and $9.5 \mathrm{~min}$ and was reduced considerably after laccase treatment without mediator (Fig. 1a, grey dotted line). The reaction with laccase and HBT showed somewhat less reduction in the Xylidine signal (Fig. 1a, upper line), which is in accordance with the results for decolorization (Table 1). In the presence of HBT alone the Xylidine signal remained unchanged (Fig. 1a, bold black broken line). In the mass spectra of Xylidine (Fig. 2a) structures representing the dye $(\mathrm{m} / \mathrm{z} 434.4430, \mathrm{~m} / \mathrm{z} 227.4508$ and $m / z$ 454.9015) almost completely disappeared after LAC_2.9 treatment, and two degradation products appeared ( $m / z$ 158.1320, 170.6363) (Fig. 2b). In the presence of HBT, no new peaks were recorded (Fig. 2c and Supplementary Material, Fig. 3), indicating that HBT is not mediating the degradation of this dye at $\mathrm{pH} 7$.

Figure $1 \mathrm{~b}$ shows the CE-UV/DAD for Methyl Orange treated or not with LAC_2.9 in presence and absence of $\mathrm{HBT}$ at $\mathrm{pH}$ 7. The dye profile appeared at $7 \mathrm{~min}$. After LAC_2.9 treatment, this peak shifted its retention time slightly and it is shown as a split peak or two unresolved peaks (Fig. 1b, grey dotted line). This may be due to loss of water for Methyl Orange treated with LAC_2.9 (as confirmed by later MS experiments); however, it does not cause a significant change in electrophoretic mobility or signal intensity, and hence, it is not evident a process of degradation. In presence of HBT, a new peak around $6.5 \mathrm{~min}$ appeared and the peak at $7 \mathrm{~min}$ decreased (Fig. 1b, bold black broken line). These results suggest that in presence of HBT a different mechanism of Methyl Orange decolorization takes place. By mass spectra, we observed that Methyl Orange $(\mathrm{m} / \mathrm{z}$ 304.3402) (Fig. 3a) decreased after laccase treatment, while a new structure $(\mathrm{m} / \mathrm{z} 288.3408)$ that could be attributed to dehydrated 
Fig. 1 Electropherograms of Xylidine (a) and Methyl Orange (b) at $254 \mathrm{~nm}$ : non-treated dye; dye treated with LAC_2.9; dye treated with only HBT; dye treated with HBT and LAC_2.9. Electropherograms of HBT alone and HBT + LAC_2.9 at $254 \mathrm{~nm}$ as controls in (c)

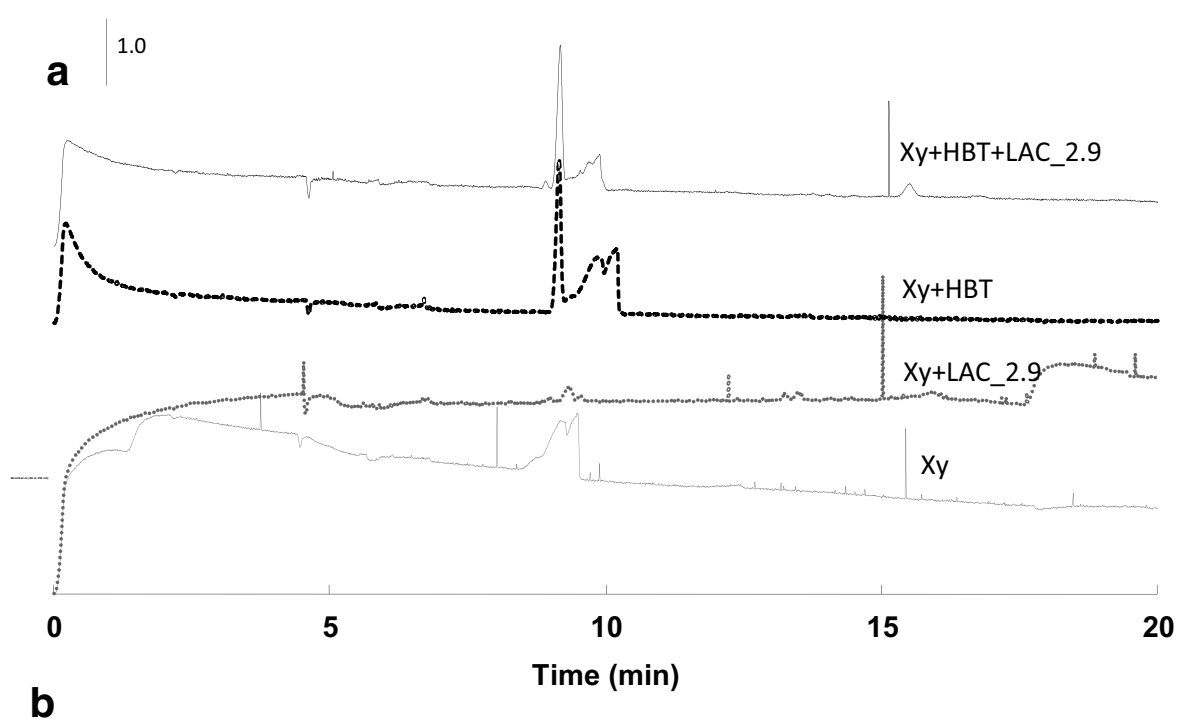

b

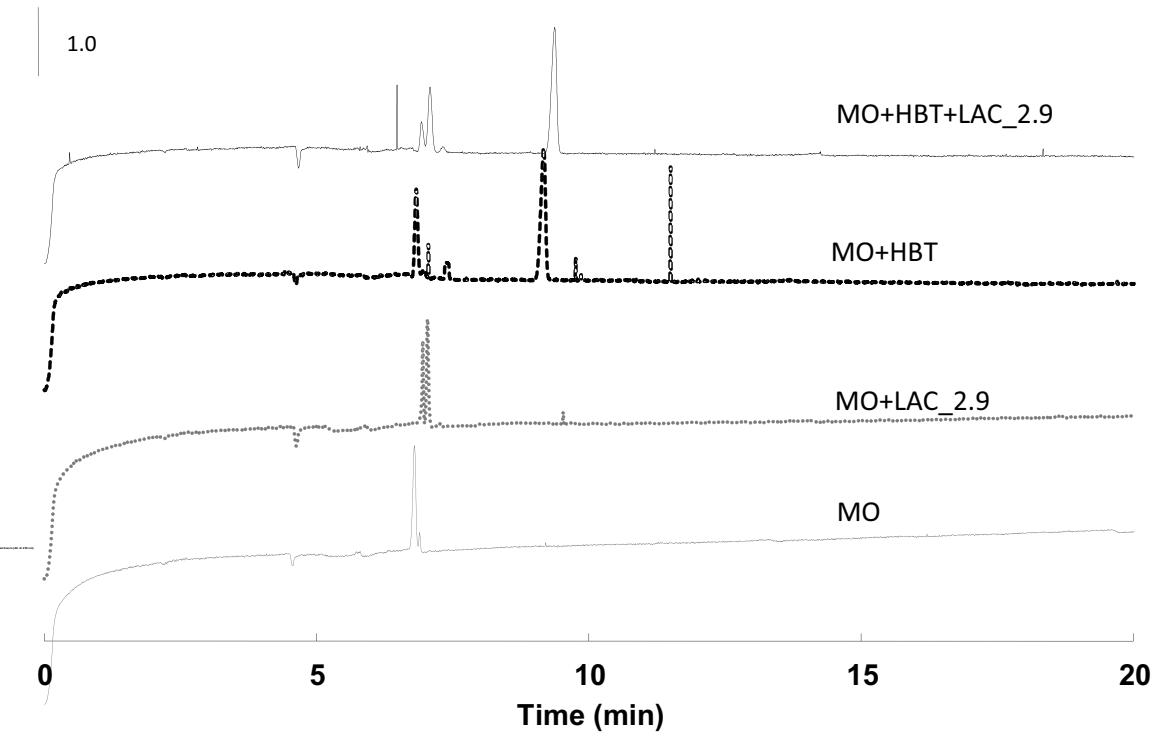

C

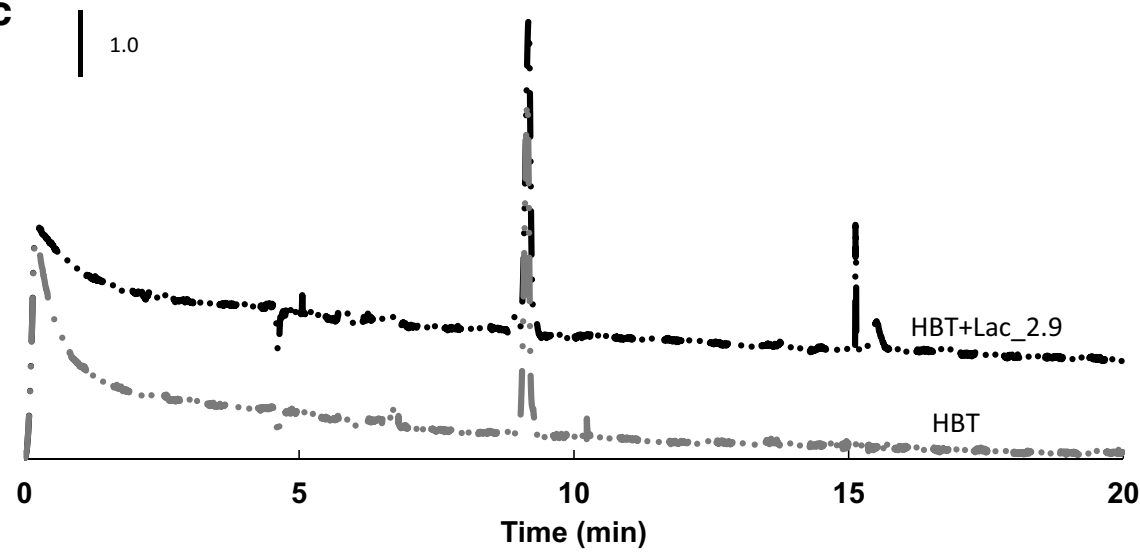

Methyl Orange appeared (Fig. 3b). This structure, with a lower conjugation degree, might be responsible for the observed change in color intensity (Table 1), but no evidence of degradation is shown. When HBT was supplied to the reaction, we observed differences in the mechanism of decolorization: a decrease in dye structure intensity at $m / z 304.3402$ and 288.3408, accompanied by at least two peaks of lower $\mathrm{m} / z$, possibly degradation products 

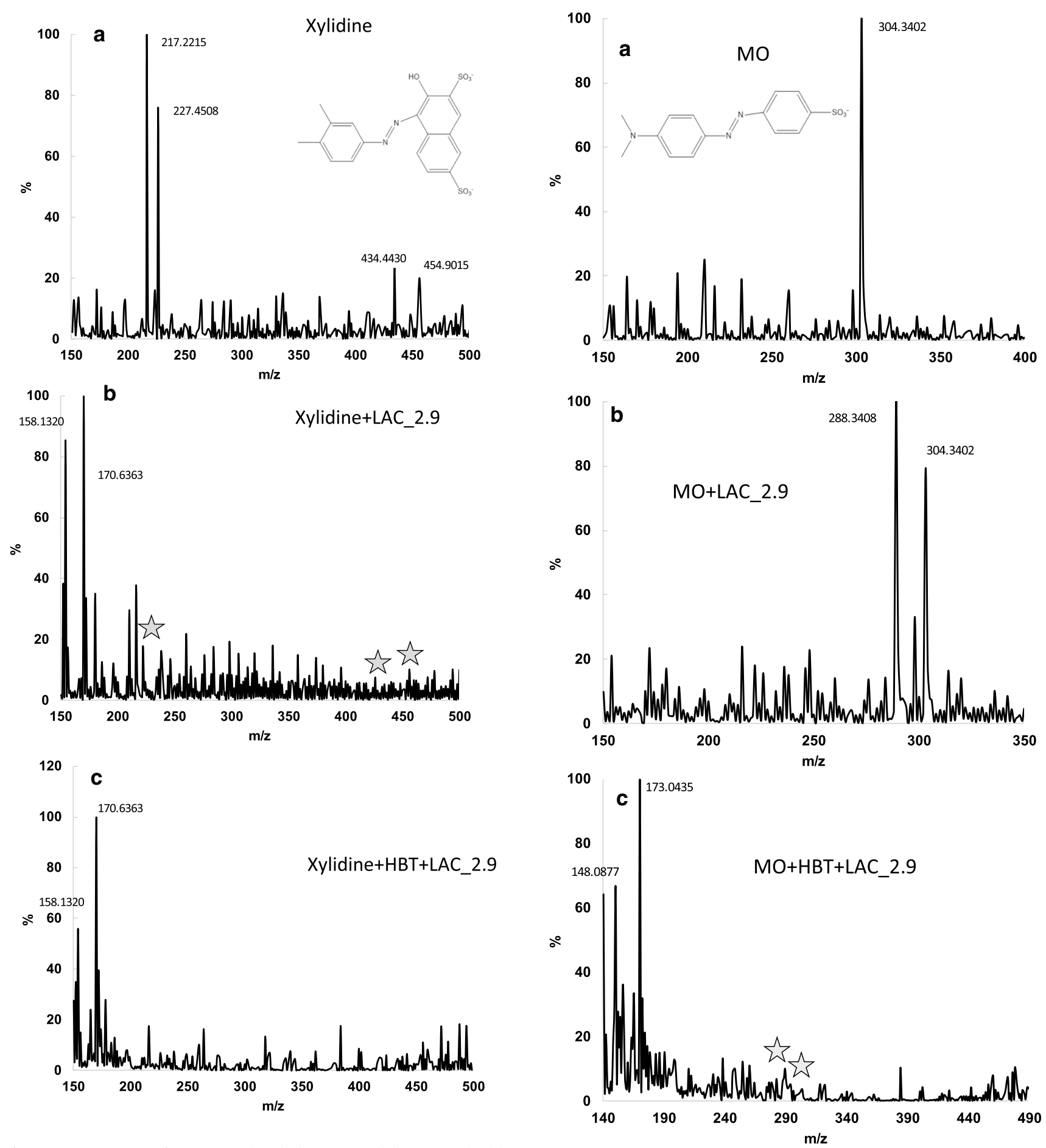

Fig. 2 Mass spectra of non-treated Xylidine (a), Xylidine treated with LAC_2.9 (b), Xylidine treated with HBT and LAC_2.9 (c). Stars indicate decreased signals

(Fig. 3c). These peaks were not observed with HBT without laccase (Supplementary Material, Fig. 4). Taking together, these results indicate that HBT acts as mediator in the degradation of Methyl Orange by LAC_2.9. A proposed mechanism is shown in Fig. 4, where HBT forms a radical cation which co-oxidizes the dye. The necessity of

Fig. 3 Mass spectra of non-treated Methyl Orange (a), Methyl Orange treated with LAC_2.9 (b), Methyl Orange treated with HBT and LAC_2.9 (c). Stars indicate decreased signals

a redox mediator to conduce degradation of Methyl Orange could be due to the lack of a phenolic $-\mathrm{OH}$ in the vicinity of the azo bond $(-\mathrm{N}=\mathrm{N}-)$. In contrast, the $-\mathrm{OH}$ close to the azo bond in the Xylidine molecule would allow the generation of a phenoxyl radical (Almansa et al. 2004; 

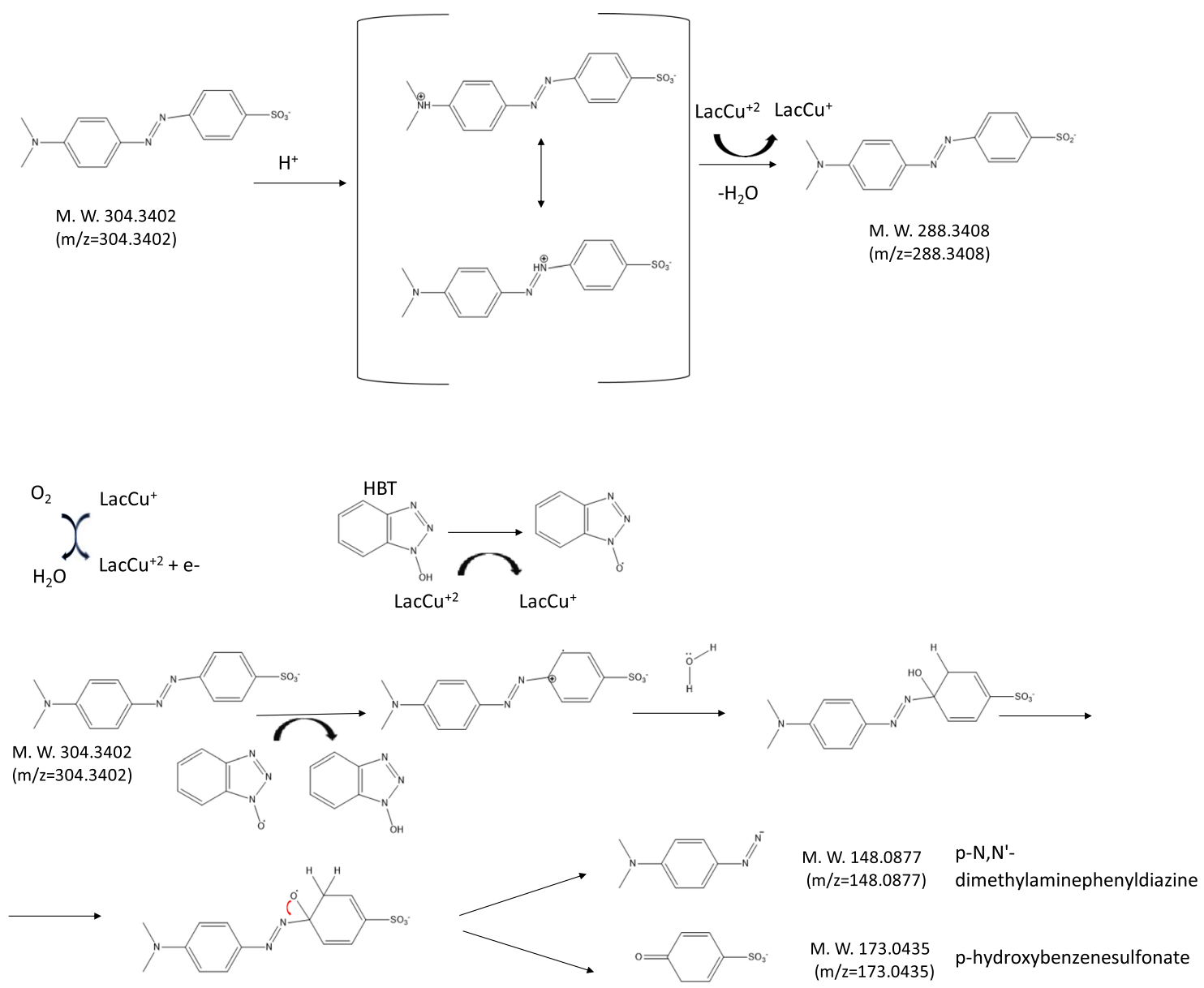

Fig. 4 Proposed degradation pathway for Methyl Orange by LAC_2.9 (a), and by LAC_2.9 in the presence of HBT (b)

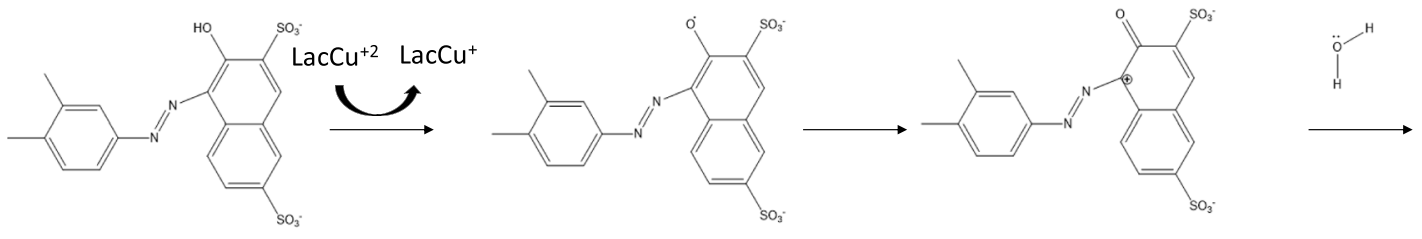

M. W. 434.4430
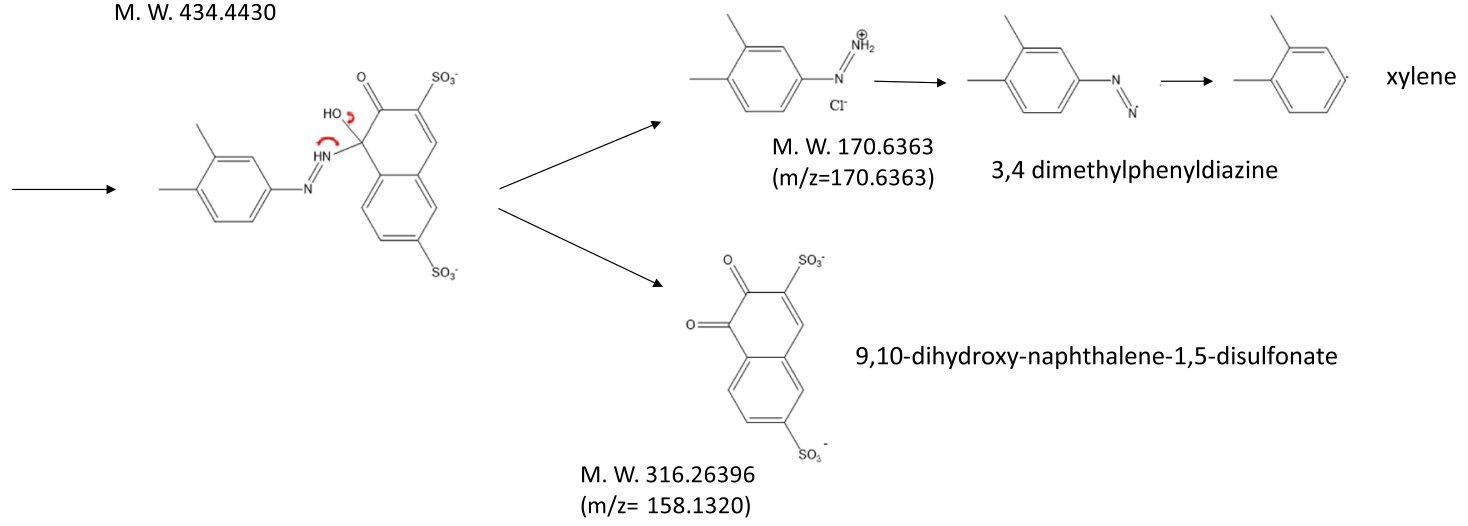

Fig. 5 Proposed degradation pathway for Xylidine by LAC_2.9 in the presence of HBT 


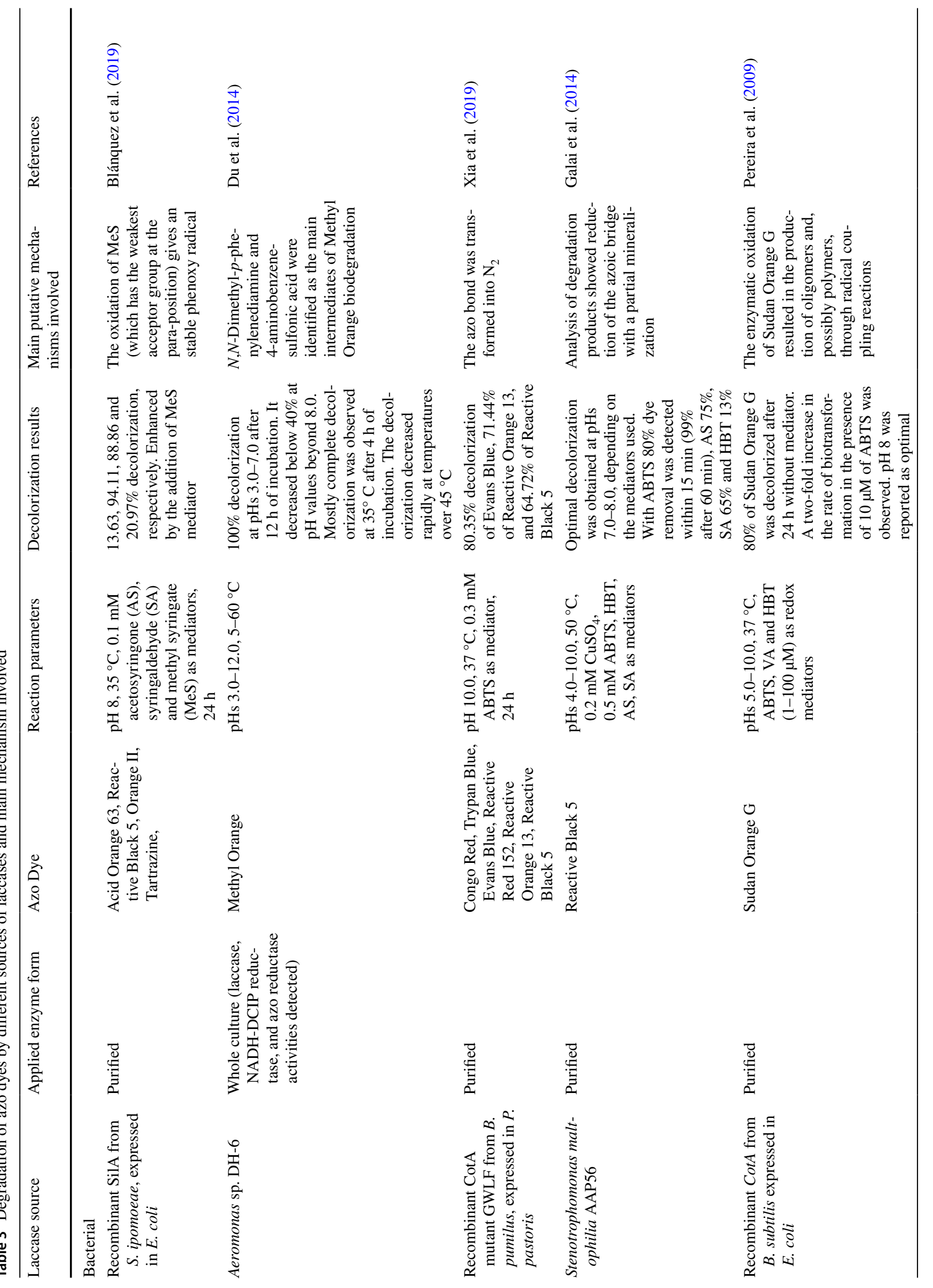




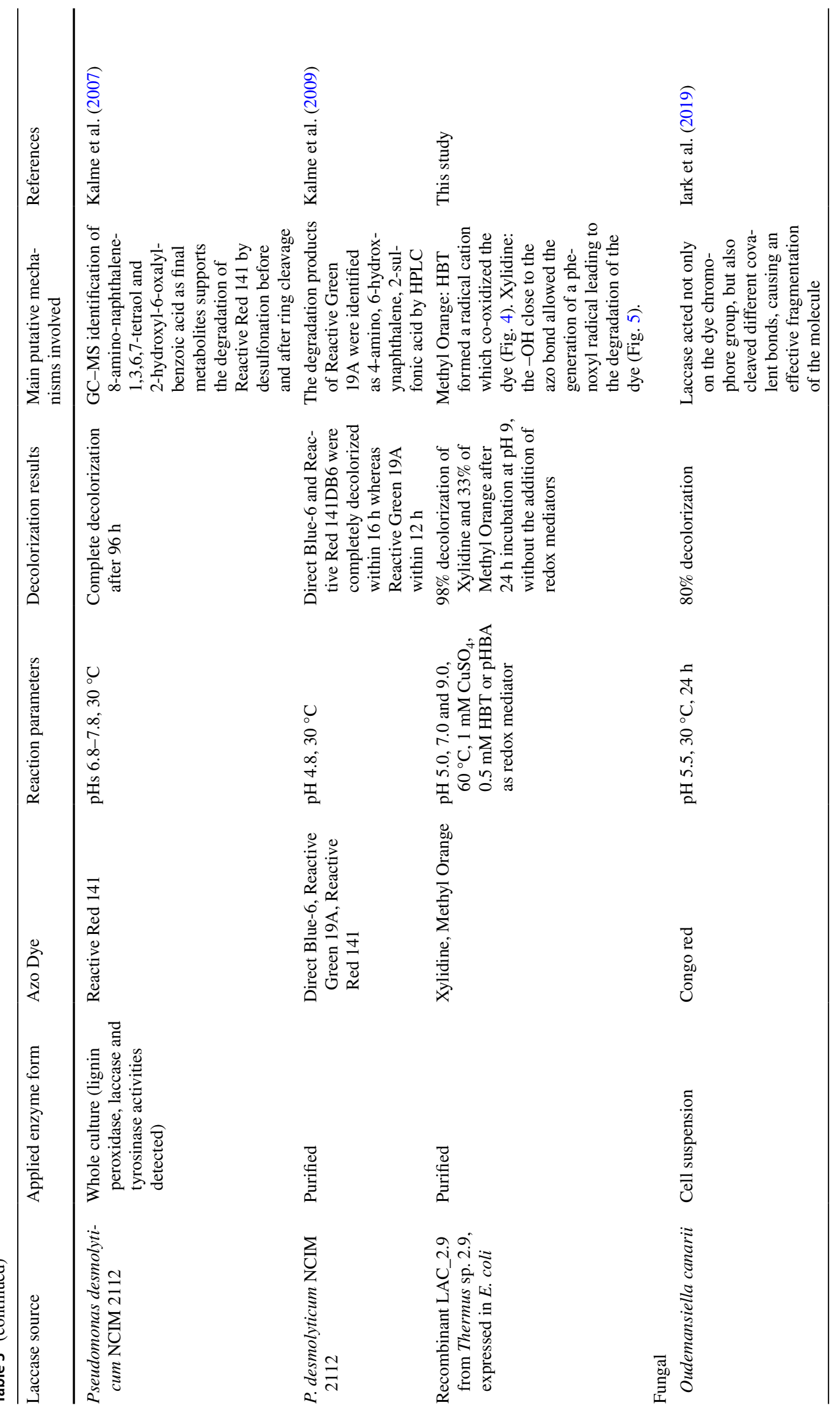




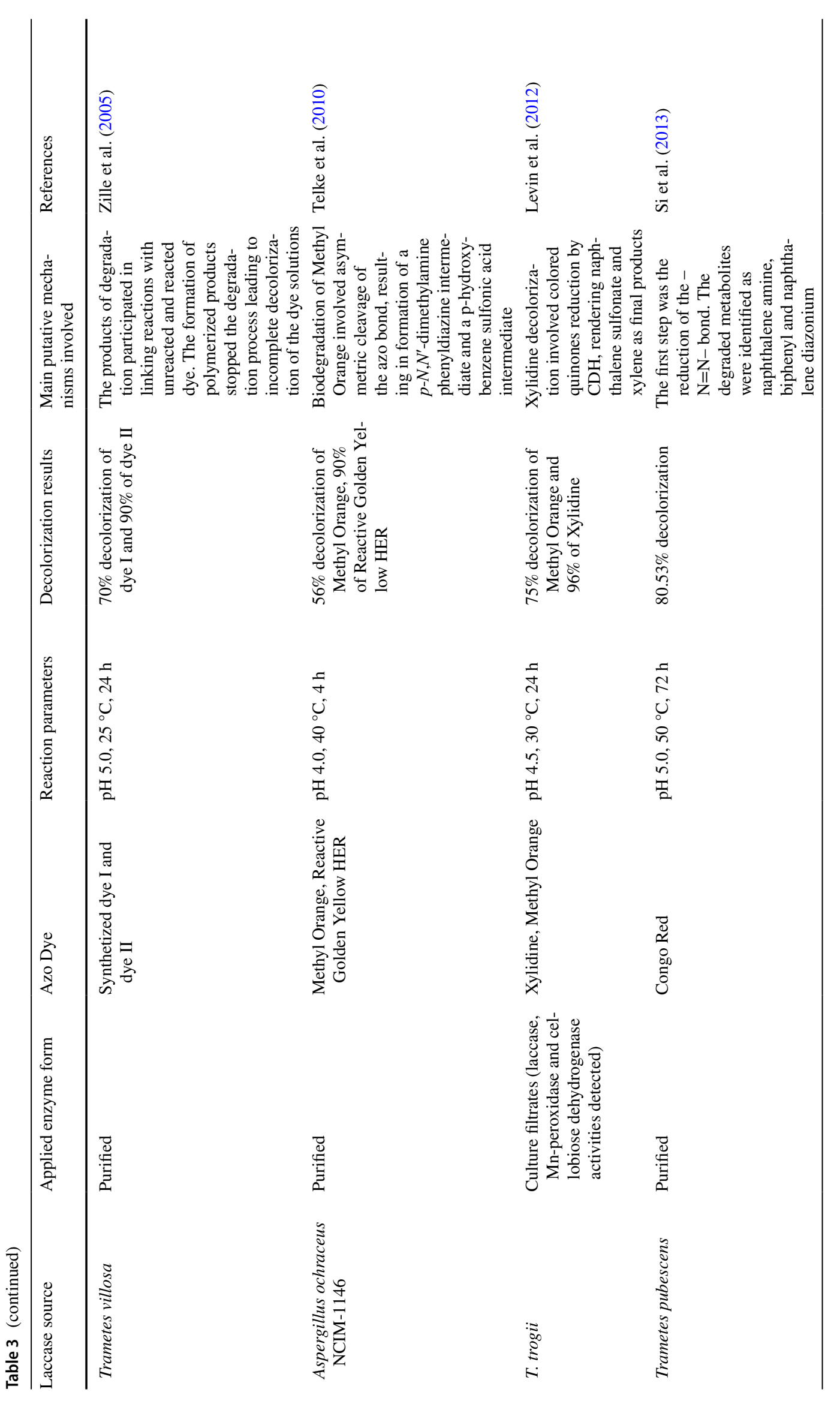




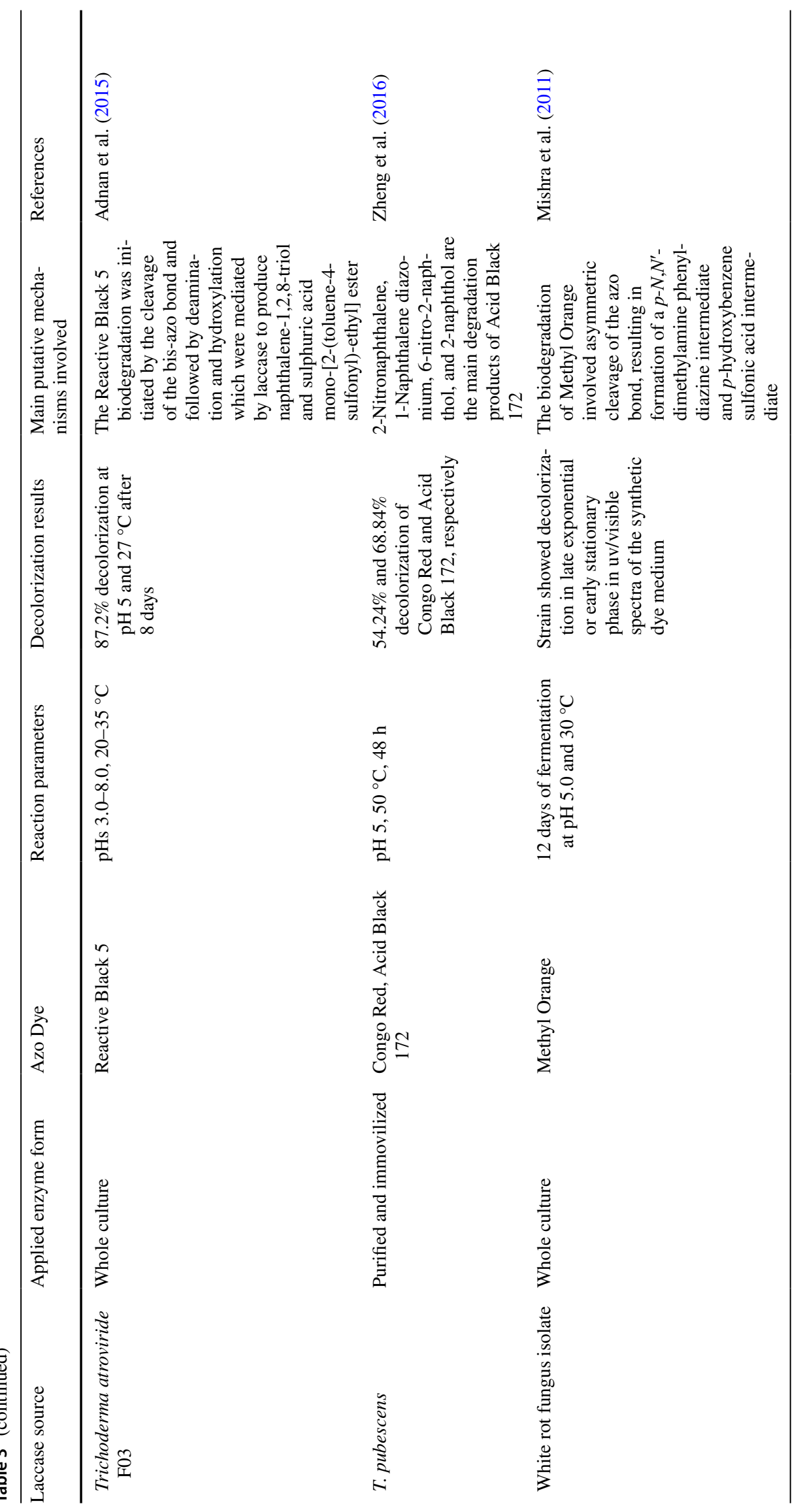


Enayatzamir et al. 2009) leading to the degradation of the chromophoric structure of the dye through the mechanism we propose in Fig. 5.

While the degradation of azo dyes has been extensively studied using cultures of a wide range of fungi and bacteria, work carried out using their purified enzymes is more limited. Table 3 summarizes the reports proposing a possible mechanism for the degradation of azo dyes obtained by using either a purified laccase as the sole enzyme or a culture fraction with laccase among other enzymatic activities. Possible degradation pathways for Methyl Orange were reported for fungal laccases (Telke et al. 2010; Mishra et al. 2011; Levin et al. 2012) as well as for the bacterium Aeromonas sp. DH-6 (Du et al. 2014). In this last case laccase as well as NADH-DCIP reductase and azo reductase activities contributed to azo dye degradation. Generally, the azoreductase catalyzes the initial step of bacterial azo degradation (reductive cleavage of the azo bond) and laccase is involved in the oxidation of sulfonated azo dyes. In the case of Aeromonas sp. DH-6, aromatic amines were obtained as intermediates in the biodegradation of Methyl Orange. As far as we know, these mechanisms have not been reported for purified bacterial laccases up to now. LAC_2.9 activity involved asymmetric cleavage of the azo bond obtaining $p$-hydroxybenzenesulfonate and $p-N, N^{\prime}$ - dimethylamine phenyldiazine as degradation products, which resemble those obtained by fungal laccases (Telke et al. 2010; Mishra et al. 2011; Levin et al. 2012). In this work, we show that a purified bacterial laccase could catalyze the decolorization of Methyl Orange without generation of aromatic amines. Additionally, we present insights into the mechanism of purified laccase action on the azo dye Xylidine. Culture filtrates from the white rot fungus Trametes trogii displaying laccase, Mn-peroxidase and cellobiose dehydrogenase activities were used for Xylidine decolorization and biodegradation products were determined (Levin et al. 2012). The same intermediaries were observed after LAC_2.9 treatment demonstrating that it catalyzes Xylidine degradation without the requirement of extra enzymes.

There are few reports on the detoxification of textile effluents with laccases, and no strict association was found between decolorization and detoxification (Adedayo et al. 2004; Anastasi et al. 2011; Legerská et al. 2018). The degradation of azo-dyes might generate compounds of increased toxicity (Zaharia and Suteu 2012). Toxicity changes after LAC_2.9 decolorization must still be evaluated. Nevertheless, recent decolorization studies involving bacterial laccases proved their ability to detoxify several azo dyes (Blánquez et al. 2019; Lade et al. 2015; Molina-Guijarro et al. 2009; Pereira et al. 2009; Xia et al. 2019).

\section{Conclusions}

There is growing interest in assessing the potential of bacterial laccases for industrial and environmental applications especially in hostile conditions. LAC_2.9 laccase from Thermus sp. 2.9 was capable of partially decolorizing chemically diverse dyes such as the azoic Xylidine and Methyl Orange, the antraquinonic RBBR, and the triphenylmethane Gentian Violet, without the addition of redox mediators even at $\mathrm{pH}$ 9 and $60{ }^{\circ} \mathrm{C}$. Due to the thermal properties of LAC_2.9 and its tolerance to alkaline pHs and high heavy metals concentrations, this enzyme could be used in the decolorization of textile effluents, a process usually performed at high temperature $\left(>55^{\circ} \mathrm{C}\right)$ and neutral/alkaline $\mathrm{pH}$. Degradation pathways are suggested for the action of LAC_2.9 on Xylidine and Methyl Orange azo dyes, not reported for purified bacterial laccases previously.

Acknowledgements We thank Irma Fuxan for the technical support in routine laboratory protocols and Dr. Morgan Fetherolf for the critical reading of the manuscript. LN was granted a fellowship from CONICET. RC, LL, and MB are staff members of CONICET. This work was supported by Instituto Nacional de Tecnología Agropecuaria (INTA) (Grant Number PNAIyAV-1130034), Consejo Nacional de Investigaciones Científicas y Técnicas (CONICET, Argentina) and University of Buenos Aires.

Author contributions LN obtained and purified the enzyme and performed the decolorization experiments. RC performed the $\mathrm{CE}$ and MS analysis and the statistical analysis of decolorization experiments. LL and MB conceived the study and MB supervised the project. All authors have contributed to the writing and revising of the manuscript and approved the final version to be submitted.

\section{Compliance with ethical standards}

Conflict of interest The authors declare that they have no conflict of interest.

\section{References}

Adedayo O, Javadpour S, Taylor C, Anderson WA, Moo-Young M (2004) Decolourisation and detoxification of methyl red by aerobic bacteria from a wastewater treatment plant. J Microbiol Biotechnol 20:545-550. https://doi.org/10.1023/b.wibi.0000043150 $.37318 .5 \mathrm{f}$

Adnan LA, Sathishkumar P, Mohd Yusoff AR, Hadibarata T (2015) Metabolites characterisation of laccase mediated Reactive Black 5 biodegradation by fast growing ascomycete fungus Trichoderma atroviride F03. Int Biodeterior Biodegrad 104:274-282. https:// doi.org/10.1016/j.ibiod.2015.05.019

Almansa E, Kandelbauer A, Pereira L, Cavaco-Paulo A, Gubitz GM (2004) Influence of structure on dye degradation with laccase mediator systems. Biocatal Biotransform 22:315-324. https:// doi.org/10.1080/10242420400024508

Anastasi A, Parato B, Spina F, Tigini V, Prigione V, Varese GC (2011) Decolourisation and detoxification in the fungal treatment of 
textile wastewaters from dyeing processes. N Biotechnol 29:3845. https://doi.org/10.1016/j.nbt.2011.08.006

Blánquez A, Rodríguez J, Brissos V, Mendes S, Martins LO, Ball AS, Arias ME, Hernández M (2019) Decolorization and detoxification of textile dyes using a versatile Streptomyces laccase-natural mediator system. Saudi J Biol Sci 26:913-920. https://doi. org/10.1016/j.sjbs.2018.05.020

Burriel Marti F, Lucena Conde F, Arribas Jimeno S, Hernández Méndez J (2002) Química analítica cualitativa. International Thomson Editores Spain, Madrid

Ciullini I, Tilli S, Scozzafava A, Briganti F (2008) Fungal laccase, cellobiose dehydrogenase, and chemical mediators: combined actions for the decolorization of different classes of textile dyes. Bioresour Technol 99:7003-7010. https://doi.org/10.1016/j.biort ech.2008.01.019

Collivignarelli M, Abbà A, Carnevale Miino M, Damiani S (2019) Treatments for color removal from wastewater: state of the art. J Environ Manag 236:727-745. https://doi.org/10.1016/j.jenvm an.2018.11.094

Di Rienzo JA, Casanoves F, Balzarini MG, Gonzalez L, Tablada M, Robledo CW (2017) InfoStat versión 2017. Grupo InfoStat, FCA, Universidad Nacional de Córdoba, Argentina. http://www.infos tat.com.ar

Du LN, Li G, Xu FC, Pan X, Wen LN, Wang Y (2014) Rapid decolorization of methyl orange by a novel Aeromonas sp. strain DH-6. Water Sci Technol 69:2004-2013. https://doi.org/10.2166/ wst.2014.099

Enayatzamir K, Tabandeh F, Yakhchali B, Alikhani HA, Rodríguez Couto S (2009) Assessment of the joint effect of laccase and cellobiose dehydrogenase on the decolouration of different synthetic dyes. J Hazard Mater 169:176-181. https://doi.org/10.1016/j. jhazmat.2009.03.088

Galai S, Korri-Youssoufi H, Marzouki MN (2014) Characterization of yellow bacterial laccase SmLac/role of redox mediators in azo dye decolorization. J Chem Technol Biotechnol 89:1741-1750. https ://doi.org/10.1002/jctb.4254

Garg SK, Tripathi M (2016) Microbial strategies for discoloration and detoxification of azo dyes from textile effluents. Res J Microbiol 12:1-19. https://doi.org/10.3923/jm.2017.1.19

Guan ZB, Luo Q, Wang HR, Chen Y, Liao XR (2018) Bacterial laccases: promising biological green tools for industrial applications. Cell Mol Life Sci 75:3569. https://doi.org/10.1007/s0001 8-018-2883-z

Iark D, dos Reis Buzzo AJ, Garcia JAA, Côrrea VG, Helm CV, Corrêa RCG, Peralta RA, Moreira RFPM, Bracht A, Peralta RM (2019) Enzymatic degradation and detoxification of azo dye Congo red by a new laccase from Oudemansiella canarii. Bioresour Technol 289:121655. https://doi.org/10.1016/j.biortech.2019.121655

Kalme S, Ghodake G, Govindwar S (2007) Red HE7B degradation using desulfonation by Pseudomonas desmolyticum NCIM 2112. Int Biodeterior Biodegrad 60:327-333. https://doi.org/10.1016/j. ibiod.2007.05.006

Kalme S, Jadhav S, Jadhav M, Govindwar S (2009) Textile dye degrading laccase from Pseudomonas desmolyticum NCIM 2112. Enzyme Microb Technol 44:65-71. https://doi.org/10.1016/j. enzmictec.2008.10.005

Kim Y, Nicell JA (2006) Impact of reaction conditions on the laccase catalyzed conversion of bisphenol A. Bioresour Technol 197:1431-1442. https://doi.org/10.1016/j.biortech

Kokol V, Doliška A, Eichlerová I, Baldrian P, Nerud F (2007) Decolorization of textile dyes by whole cultures of Ischnoderma resinosum and by purified laccase and Mn-peroxidase. Enzyme Microb Technol 40:1673-1677. https://doi.org/10.1016/j.enzmi ctec.2006.08.015

Lade H, Kadam A, Paul D, Govindwar S (2015) Biodegradation and detoxification of textile azo dyes by bacterial consortium under sequential microaerophilic/aerobic processes. EXCLI J 14:158-174. https://doi.org/10.17179/excli2014-642

Legerská B, Chmelová D, Ondrejovič M (2018) Decolourization and detoxification of monoazo dyes by laccase from the white-rot fungus Trametes versicolor. J Biotechnol 285:84-90. https://doi. org/10.1016/jjbiotec.2018.08.011

Levin L, Grassi E, Carballo R (2012) Efficient azoic dye degradation by Trametes trogii and a novel strategy to evaluate products released. Int Biodeterior Biodegrad 75:214-222. https://doi. org/10.1016/j.ibiod.2012.10.005

Liu H, Cheng Y, Du B, Tong C, Liang S, Han S, Zheng S, Lin Y (2015) Overexpression of a novel thermostable and chloridetolerant laccase from Thermus thermophilus SG0.5JP17-16 in Pichia pastoris and its application in synthetic dye decolorization. PLoS One 10(3):e0119833. https://doi.org/10.1371/journ al.pone. 0119833

Lončar N, Božić N, Lopez-Santin J, Vujčić Z (2013) Bacillus amyloliquefaciens laccase-from soil bacteria to recombinant enzyme for wastewater decolorization. Bioresour Technol 147:177-183. https://doi.org/10.1016/j.biortech.2013.08.056

Ma S, Liu N, Jia H, Dai D, Zang J, Cao Z, Dong J (2018) Expression, purification, and characterization of a novel laccase from Setosphaeria turcica in Escherichia coli. J Basic Microbiol 58:68-75. https://doi.org/10.1002/jobm.201700212

Mandic M, Djokic L, Nikolaivits E, Prodanovic R, O'Connor K, Jeremic S, Topakas E, Nikodinovic-Runic J (2019) Identification and characterization of new laccase biocatalysts from Pseudomonas species suitable for degradation of synthetic textile dyes. Catalysts 9:629. https://doi.org/10.3390/catal9070629

Mishra A, Kumar S, Pandey A (2011) Laccase production and simultaneous decolorization of synthetic dyes in unique inexpensive medium by new isolates of white rot fungus. Int Biodeterior Biodegrad 65:487-493. https://doi.org/10.1016/j.ibiod.2011.01.011

Molina-Guijarro JM, Pérez J, Muñoz-Dorado J, Guillén F, Moya R, Hernández M, Arias ME (2009) Detoxification of azo dyes by a novel $\mathrm{pH}$-versatile, salt-resistant laccase from Streptomyces ipomoea. Int Microbiol 12:13-21. https://doi. org/10.2436/20.1501.01.77

Mongay C, Cerdà V (1974) A Britton-Robinson buffer of known ionic strength. Ann Chim 64:409-412

Moya R, Hernández M, García-Martín AB, Ball AS, Arias ME (2010) Contributions to a better comprehension of redox-mediated decolouration and detoxification of azo dyes by a laccase produced by Streptomyces cyaneus CECT 3335. Bioresour Technol 101:22242229. https://doi.org/10.1016/j.biortech.2009.11.061

Navas LE, Martínez FD, Taverna ME, Fetherolf MM, Eltis LD, Nicolau V, Estenoz D, Campos E, Benintende GB, Berretta MF (2019) A thermostable laccase from Thermus sp. 2.9 and its potential for delignification of Eucalyptus biomass. AMB Express 9(1):24. https://doi.org/10.1186/s13568-019-0748-y

Parshetti GK, Kalme SD, Saratale GD, Govindwar SP (2006) Biodegradation of malachite green by Kocuria rosea MTCC 1532. Acta Chim Slov 53:492-498

Pereira L, Coelho AV, Viegas CA, dos Santos MMC, Robalo MP, Martins LO (2009) Enzymatic biotransformation of the azo dye Sudan Orange $\mathrm{G}$ with bacterial CotA-laccase. J Biotechnol 139:68-77. https://doi.org/10.1016/j.jbiotec.2008.09.001

Si J, Peng F, Cui B (2013) Purification, biochemical characterization and dye decolorization capacity of an alkali-resistant and metaltolerant laccase from Trametes pubescens. Bioresour Technol 128:49-57. https://doi.org/10.1016/j.biortech.2012.10.085

Singh RL, Singh PK, Singh RP (2015) Enzymatic decolorization and degradation of azo dyes-a review. Int Biodeterior Biodegrad 104:21-31. https://doi.org/10.1016/j.ibiod.2015.04.027 
Takeda S, Tanaka Y, Nishimura Y, Yamane M, Siroma Z, Wakida S (1999) Analysis of dyestuff degradation products by capillary electrophoresis. J Chromatogr A 853:503-509. https://doi. org/10.1016/s0021-9673(99)00579-8

Telke AA, Kadam AA, Jagatap SS, Jadhav JP, Govindwar SP (2010) Biochemical characterization and potential for textile dye degradation of blue laccase from Aspergillus ochraceus NCIM-1146. Biotechnol Bioprocess Eng 15:696-703. https://doi.org/10.1007/ s12257-009-3126-9

Thakur JK, Paul S, Dureja P, Annapurna K, Padaria JC, Gopal M (2014) Degradation of sulphonated azo dye Red HE7B by Bacillus sp. and elucidation of degradative pathways. Curr Microbiol 69:183-191. https://doi.org/10.1007/s00284-014-0571-2

Torres E, Bustos-Jaimes I, Borgne SL (2003) Potential use of oxidative enzymes for the detoxification of organic pollutants. Appl Catal B-Environ 46:1-15. https://doi.org/10.1016/s0926-3373(03)00228 $-5$

Unuofin JO, Okoh AI, Nwodo UU (2019) Aptitude of oxidative enzymes for treatment of wastewater pollutants: a laccase perspective. Molecules 24:2064. https://doi.org/10.3390/molecules2 4112064

Verma A, Shirkot P (2014) Purification and characterization of thermostable laccase from thermophilic Geobacillus thermocatenulatus MS5 and its applications in removal of textile dyes. Sch Acad J Biosci 2:479-485
Xia J, Wang Q, Luo Q, Chen Y, Liao XR, Guan ZB (2019) Secretory expression and optimization of Bacillus pumilus CotAlaccase mutant GWLF in Pichia pastoris and its mechanism on Evans blue degradation. Process Biochem 20:33-41. https://doi. org/10.1016/j.procbio.2018.12.034

Zaharia C, Suteu D (2012) Textile organic dyes. Characteristics, polluting effects and separation/elimination procedures from industrial effluents. A critical overview. In: Tomasz P (ed) Organic pollutants ten years after the Stockholm Convention. Environmental and analytical update. IntechOpen. https://doi.org/10.5772/32373

Zheng F, Cui BK, Wu XJ, Meng G, Liu HX, Si J (2016) Immobilization of laccase onto chitosan beads to enhance its capability to degrade synthetic dyes. Int Biodeterior Biodegrad 110:69-78. https://doi. org/10.1016/j.ibiod.2016.03.004

Zille A, Gornacka B, Rehorek A, Cavaco-Paulo A (2005) Degradation of azo dyes by Trametes villosa laccase over long periods of oxidative conditions. Appl Environ Microbiol 71:6711-6718. https:// doi.org/10.1128/aem.71.11.6711-6718.2005

Publisher's Note Springer Nature remains neutral with regard to jurisdictional claims in published maps and institutional affiliations. 